\title{
PENGARUH KEPUASAN PASIEN TERHADAP TINGKAT PELAYANAN PUSKESMAS MEDANG KAMPAI DENGAN MENGGUNAKAN METODE KANO
}

\author{
Trisna Mesra \\ Staf Pengajar Program Studi Teknik Industri Sekolah Tinggi Teknologi Dumai, \\ Jl. Utama Karya Bukit Batrem Dumai Riau \\ E-mail:trisnamesra74@gmail.com
}

\begin{abstract}
ABSTRAK
Puskesmas sebagai salah satu institusi pemberi pelayanan kesehatan harus mampu memberikan pelayanan kesehatan yang bermutu dimana kepuasaan pada diri tiap pasien dapat di rasakan bila harapan dan kebutuhan pasien terpenuhi.

Penelitan ini bertujuan untuk menentukan tingkat kepuasan pasien rawat jalan terhadap pelayanan Puskesmas Medang Kampai, digunakan metode kano untuk mengelompokan customer requirement ke dalam lima kategori yaitu must be, one dimensional, attraktive, indifferent dan reverse. Hasil pengolahan data dan analisis yang telah dilakukan didapat kesimpulan bahwa atribut yang mempengaruhi kepuasaan pelayanan pasien Puskesmas Medang Kampai adalah Kecepatan merespon keluhan pasien, keteraturan lapangan parkir, kebersihan lingkungan Puskesmas, kerapian penampilan petugas, perhatian petugas terhadap pasien, kebaikan fasilitas Puskesmas, keramahan dan kesopanan petugas.

Sedangkan atribut yang mempengaruhi ketidakpuasan pasien Puskesmas Medang Kampai adalah pihak puskesmas kurang cepat merespon keluhan pasien. Kondisi fisik fasilitas, puskesmas harus akurat dalam pelayanan.Perbaikan yang harus dilakukan adalah prosedur pelayanan, lingkungan puskesmas, kondisi lapangan parkir dan perhatian petugas pada pasien.
\end{abstract}

Kata kunci: Satisfaction,Puskesmas, Kano.

\section{Pendahuluan}

Kotler dalam Wijaya (2011) menyatakan bahwa kepuasan pelanggan adalah perasaan seseorang setelah membandingkan kinerja (hasil) yang ia rasakan dibandingkan dengan harapannya.Sedangkan Soetopo dalam Napitupulu (2012) mendefinisikan pelayanan sebagai "suatu usaha untuk membantu menyiapkan (mengurus) apa yang diperlukan orang lain". Dari definisi-definisi pelayanan tersebut di atas dapat dirangkum mengenai pengertian pelayanan yaitu suatu tindakan atau aktivitas seseorang atau sekelompok orang untuk memenuhi kebutuhan dan harapan pelanggan atau pengguna layanan.

Puskesmas sebagai salah institusi pemberi pelayanan kesehatan harus mampu memberikan pelayan kesehatan yang bermutu. Pelayanan yang bermutu merujuk kepada tingkat kesempurnaan pelayanan kesehatan dalam menimbulkan kepuasan pada diri tiap Pasien. Kepuasaan pada diri tiap Pasien dapat di rasakan bila harapan dan kebutuhan Pasien terpenuhi, namun bila tidak sesuai dengan kebutuhan dan harapan Pasien,maka yang dirasakan Pasien adalah ketidakpuasan.

Puskesmas merupakan suatu tempat untuk melakukan upaya peningkatan kesehatan, mencegah dan menyembuhkan penyakit serta memulihkan kesehatan.Puskesmas harus bisa menjamin mutu pelayanan keperawatan melalui kesesuaian dengan kebutuhan Pasien. Penting peningkatan mutu pelayanan puskesmas adalah untuk membangun persahabatan yang 
mendorong hubungan dengan pasien sehingga Puskesmas tidak ditingalkan oleh pasiennya (Azwar,2008). Penelitian ini akan menganalisa bagaimana tingkat kepuasan Pasien rawat jalan dan apa saja penyebab timbulnya rasa ketidakpuasan Pasien rawat jalan terhadap pelayanan Puskemas Medang Kampai.

\section{TINJAUAN PUSTAKA}

Usulan Peningkatan Kualitas Pelayanan PT. X Universitas Al Azhar Indonesia dengan Metode Servqual dan Kano yang dilakukan oleh Niken dkk (2011) menunjukan masih banyaknya pelayanan yang belum sesuai dengan harapan pelanggan. Perbaikan yang dibutuhkan berdasarkan hasil kuesioner 3 tertingi yaitu tersedianya minuman gratis untuk customer, kebersihan ruangan dan pengelolahan parkir. Adapun pertimbangan dari segi keuangan, waktu, dan sumber daya manusia serta kemudahan pelaksana.

Sedangkan Analisis Atribut Produk yang mempengaruhi kategori kepuasan konsumen dengan Metode Kano oleh Aprilina dkk (2012) yang menunjukan bahwa atribut yang termasuk dalam kategori attractive adalah bahan kemasaan yang ramah lingkungan, kepraktisan kemasaan dan kepercantuman komposisi pada kemasaan. Atribut yang termasuk kategori one dimensional yaitu atribut penambahan variasi rasa dan isi dalam roti, jenis, bentuk roti, ukuran roti yang bermacam-macam, warna dan bentuk kemasaan yang menarik serta pencantuman tanggal kadarluasa pada kemasaan. Atribut yang termasuk indiffrent yaitu adanya peningkatan harga sesuai dengan peningkatan kualitas produk. Atribut yang perlu diperbaiki yaitu atribut pencantuman tangal kadarluasa pada kemasaan.

\section{Metode Penelitian}

Penelitian ini diawali dengan penelitian pendahuluan untuk mencari permasalahan yang dihadapi dan mengidentifikasikannya selanjutnya menetapkan tujuan penelitian, mengumpulkan data, pengolahan data dan kesimpulan. Sampel dalam penelitian ini sebanyak 92 orang yang ditentukan dengan menggunakan rumus Slovin untuk menentukan jumlah sampel. Teknik pengambilan sampel yang dipakai adalah Sampling Insidental yaitu teknik penentuan sampel berdasarkan kebetulan, yaitu siapa saja yang secara kebetulan bertemu dengan peneliti digunakan sebagai sampel.

Analisis kualitas layanan dilakukan dengan metode Kano. Langkah-langkah pengukuran kualitas layanan dengan metode kano yang sudah di adaptasi dengan servqual yaitu :

a. Identifikasi atribut.

b. Tes pra-kuesioner Kano berdimensi Servqual. Penyusunan Kuesioner

c. Langkah-langkah untuk mengklasifikasikan atribut berdasarkan metode Kano adalah sebagai berikut :

1) Menentukan atribut tiap responden (perhatikan tabel 1)

Tabel 1. Penentuan Kategori Kano

\begin{tabular}{|c|c|c|c|c|c|}
\hline \multirow{2}{*}{\multicolumn{2}{|c|}{ Customer }} & \multicolumn{4}{|c|}{ Dysfunctional } \\
\cline { 3 - 6 } Requirement & & 1 & 2 & 3 & 4 \\
\hline \multirow{3}{*}{ fungsional } & 1 & $\mathrm{Q}$ & $\mathrm{A}$ & $\mathrm{A}$ & $\mathrm{O}$ \\
\cline { 3 - 7 } & 2 & $\mathrm{R}$ & $\mathrm{I}$ & $\mathrm{I}$ & $\mathrm{M}$ \\
\cline { 2 - 6 } & 3 & $\mathrm{R}$ & $\mathrm{I}$ & $\mathrm{I}$ & $\mathrm{M}$ \\
\cline { 2 - 6 } & 4 & $\mathrm{R}$ & $\mathrm{R}$ & $\mathrm{R}$ & $\mathrm{Q}$ \\
\hline
\end{tabular}

Sumber : Walden, 1993. 
Keterangan :

$\mathrm{Q}=$ Questionnable

1. Suka

2. Mengharapkan

3.Memberikan Toleransi

4. Tidak Suka $\mathrm{a}=$ Functional

$\mathrm{b}=$ Dysfunctional

$\mathrm{k}=$ Kategori Kano

Atractive

$\mathrm{I}=$ Indifferent

$\mathrm{O}=$ One dimensional

$\mathrm{M}=$ Must be

2) Menghitung jumlah masing-masing kategori Kano dalam tiap-tiap atribut

3) Menentukan kategori kano untuk tiap atribut dengan menggunakan Blauth Formula (Walden,1993) sebagai berikut:

Jika (one-dimensional + attractive + must be) $>$ (indifferent + reverse +questionable), maka grade diperoleh dari yang paling maksimum dari (one dimensional, attractive, must be). Jika (one dimensional + attractive + must be) $<$ (indifferent + reverse + questionable), maka grade diperoleh dari paling maksimum dari (indifferent,reverse, questionable).

4) Menghitung nilai better dan worse.better mengindikasikan seberapa banyak kenaikan kepuasan pelanggan jika kita menyediakan fiturnya (A \& O). Worse mengindentifikasikan seberapa banyak penurunannya kepuasan pelanggan jika kita tidak menyediakan fiturnya ( O\& M). Adapunn rumus untuk menghilangkan worse dan better adalah sebagai berikut :

$$
\begin{aligned}
\text { Better } & =\frac{A+O}{A+O+M+I} \\
\text { Worse } & =\frac{0+M}{A+O+M+I}
\end{aligned}
$$

5) Tindakan perbaikan.

\section{Hasil dan Pembahasan}

Data yang dikumpulkan dari 92 responden untuk kuesioner fungsional dan disfungsionalmempunyai 20 atribut, yang mana total dari setiap atribut dapat dilihat pada Tabel 2. Dari rekapitulasi data Tabel 2 dilakukan uji validitas, ternyata semua data tersebut valid karena semua $r$ hitung $>r$ tabel untuk setiap variabel kepuasan pasien puskesmas Medang Kampai .Selanjutnya dilakukan Uji Reliabilitas untuk setiap butir pertanyaan dan hasilnya semuanya reliabel, layak dan mempunyai keefektifan yang kuat untuk diteliti dan data - data yang dipertanyakan semuanya signifikan. 
Tabel 2. Rekapitulasi Kuesioner Fungsional dan Disfungsional untuk 92 Responden Sumber : Penelitian 2015

\begin{tabular}{|r|r|r|r|r|r|r|r|r|r|}
\hline \multicolumn{4}{|c|}{ Fungsional } & \multicolumn{5}{|c|}{ Disfungsional } \\
\hline
\end{tabular}

Berdasarkan deskripsi jawaban responden yang telah diketahui sebelumnya dapat diketahui jumlah masing - masing kategori kano sebagai gambaran jawaban dari 92 responden yang tersusun dalam sebuah rekapitulasi seperti terlihat pada Tabel 3.

Tabel 3. Rekapitulasi Kategori Kano Tiap Atribut Layanan

\begin{tabular}{|c|c|c|c|c|c|c|c|c|}
\hline \multirow{2}{*}{$\begin{array}{l}\text { Atribuat } \\
\text { Layanan }\end{array}$} & \multicolumn{6}{|c|}{ Rekapitulasi Masing - Masing Kategori Kano } & \multirow[b]{2}{*}{ Total } & \multirow[b]{2}{*}{ Grade } \\
\hline & $\mathrm{Q}$ & $\mathrm{R}$ & $\mathrm{A}$ & $\mathrm{I}$ & $\mathrm{O}$ & $\mathrm{M}$ & & \\
\hline 1 & - & - & 2 & 3 & 49 & 38 & 92 & $\mathrm{O}$ \\
\hline 2 & - & - & 5 & 5 & 46 & 36 & 92 & $\mathrm{O}$ \\
\hline 3 & - & - & 9 & 1 & 45 & 37 & 92 & $\mathrm{O}$ \\
\hline 4 & - & - & 2 & 6 & 50 & 34 & 92 & $\mathrm{O}$ \\
\hline 5 & - & - & 5 & 10 & 34 & 43 & 92 & $\mathrm{M}$ \\
\hline 6 & - & - & 4 & 10 & 33 & 45 & 92 & $\mathrm{M}$ \\
\hline 7 & - & - & 7 & 4 & 43 & 38 & 92 & $\mathrm{O}$ \\
\hline 8 & - & - & 8 & 6 & 41 & 37 & 92 & $\mathrm{O}$ \\
\hline 9 & - & - & 8 & 4 & 53 & 27 & 92 & $\mathrm{O}$ \\
\hline 10 & - & - & 10 & 7 & 32 & 43 & 92 & M \\
\hline 11 & - & - & 5 & 9 & 34 & 44 & 92 & $\mathrm{M}$ \\
\hline 12 & - & - & 3 & 5 & 21 & 44 & 92 & $\mathrm{M}$ \\
\hline 13 & - & - & 6 & 9 & 39 & 38 & 92 & $\mathrm{O}$ \\
\hline 14 & - & - & 12 & 4 & 41 & 35 & 92 & $\mathrm{O}$ \\
\hline 15 & - & - & 5 & 10 & 42 & 35 & 92 & $\mathrm{O}$ \\
\hline 16 & - & - & 6 & 5 & 37 & 44 & 92 & $\mathrm{M}$ \\
\hline 17 & - & - & 10 & 10 & 29 & 43 & 92 & $\mathrm{M}$ \\
\hline 18 & - & - & 3 & 7 & 32 & 50 & 92 & $\mathrm{M}$ \\
\hline 19 & - & - & 4 & 31 & 14 & 45 & 92 & $\mathrm{M}$ \\
\hline 20 & - & - & 3 & 6 & 46 & 37 & 92 & $\mathrm{O}$ \\
\hline
\end{tabular}




\begin{tabular}{|c|c|c|c|c|c|c|c|c|}
\hline \multirow{2}{*}{$\begin{array}{c}\text { Atribuat } \\
\text { Layanan }\end{array}$} & \multicolumn{6}{|c|}{ Rekapitulasi Masing - Masing Kategori Kano } & \multirow{2}{*}{ Total } & \multirow{2}{*}{ Grade } \\
\cline { 2 - 8 } & $\mathrm{Q}$ & $\mathrm{R}$ & $\mathrm{A}$ & $\mathrm{I}$ & $\mathrm{O}$ & $\mathrm{M}$ & \multirow{2}{*}{ Tota } \\
\hline Total & - & - & 117 & 129 & 782 & 812 & 1840 \\
\hline$\%$ & - & - & $6,4 \%$ & $7 \%$ & $42,5 \%$ & $44,1 \%$ & $100 \%$ \\
\hline
\end{tabular}

Sumber: Penelitian, 2016

Berdasarkan rekapitulasi kategori kano tiap atribut dapat diketahui terdapat empat kategori kano yang dipilih oleh responden yaitu kategori kano attractive, must be, one dimensional, dan indifferent. Dimana jumlah masing-masing kategori tersebut dapat dilihat di Tabel 2.

Dimensi serqual yang memperoleh kategori one dimensional adalah tangible, assurance. Sedangkan dimensi responsiveness, emphaty dan reliability termasuk kategori must be.Atribut yang paling berpengaruh terhadap kepuasan pasien berdasarkan dimensi serqual adalah sebagai berikut.Untuk dimensi tangible seluruh atribut mendapat kategori one dimensional. Pada dimensi reliability atribut administrasi dan pelayanan mendapat kategori must be dan atribut prosedur pelayanan puskesmas dan kesopanan serta keramahan pelayan puskesmas mendapat kategori one dimensional. Dimensi Responsiveness tiga atribut mendapat kategori must be dan satu atribut (kinerja pelayan puskesmas) mendapat kategori one dimensional. Sementara dimensi assurance hampir semua atribut mendapat kategori one dimensional kecuali atribut inisiatif petugas dalam membantu pasien mendapat kategori must be. Sedangkan dimensi emphaty hampir semua atribut mendapat kategori must be dan atribut perhatian petugas pada pasien mendapt kategori one dimensional.

\section{Frekuensi jawaban responden}

Mengacu pada jawaban responden diatas maka dapat dilihat frekuensi kategori kano terbanyak dari seluruh jwaban atas masing - masing pertanyaan yang diberikan pada responden adalah sebagai berikut:

Tabel 4. Frekuensi Jawaban Responden Tertinggi

\begin{tabular}{|l|c|c|c|}
\hline \multicolumn{1}{|c|}{ Atribut Layanan } & $\begin{array}{c}\text { Jawaban } \\
\text { Tertinggi }\end{array}$ & $\begin{array}{c}\text { Jawaban } \\
\text { Kedua } \\
\text { Tertinggi }\end{array}$ & $\begin{array}{c}\text { Jawaban } \\
\text { Ketiga } \\
\text { Tertinggi }\end{array}$ \\
\hline 1. Kebersihan lingkungan Puskesmas & $\mathrm{O}$ & $\mathrm{M}$ & $\mathrm{I}$ \\
\hline 2.Penampilan karyawan & $\mathrm{O}$ & $\mathrm{M}$ & - \\
\hline 3.Kondisi fisik fasilitas & $\mathrm{O}$ & $\mathrm{M}$ & $\mathrm{A}$ \\
\hline 4.Kondisi lapangan parkir & $\mathrm{O}$ & $\mathrm{M}$ & $\mathrm{I}$ \\
\hline 5.Proses pelayanan administrasi & $\mathrm{M}$ & $\mathrm{O}$ & $\mathrm{I}$ \\
\hline 6.Pelayanan pihak puskesmas & $\mathrm{M}$ & $\mathrm{O}$ & $\mathrm{I}$ \\
\hline 7. Prosedur pelayanan puskesmas & $\mathrm{O}$ & $\mathrm{M}$ & $\mathrm{A}$ \\
\hline $\begin{array}{l}\text { 8. Kesopanaan dan keramahan melayani } \\
\text { pasien. }\end{array}$ & $\mathrm{O}$ & $\mathrm{M}$ & $\mathrm{A}$ \\
\hline $\begin{array}{l}\text { 9. Kinerja petugas cepat merespon keluhan } \\
\text { pasien. }\end{array}$ & $\mathrm{O}$ & $\mathrm{M}$ & $\mathrm{A}$ \\
\hline $\begin{array}{l}\text { 10. Kinerja petugas dalam bersedia } \\
\text { membantu kesulitan pasien }\end{array}$ & $\mathrm{M}$ & $\mathrm{O}$ & $\mathrm{A}$ \\
\hline $\begin{array}{l}\text { 11. Kinerja petugas dalam menyampaikan } \\
\text { informasi kepada pasien }\end{array}$ & $\mathrm{M}$ & $\mathrm{O}$ & $\mathrm{I}$ \\
\hline $\begin{array}{l}\text { 12.Kinerja petugas dalam cepat tangap } \\
\text { menyelesaikan keluhan pelangan. }\end{array}$ & $\mathrm{M}$ & $\mathrm{O}$ & $\mathrm{I}$ \\
\hline \multicolumn{1}{|l|}{} & $\mathrm{M}$ & $\mathrm{A}$ \\
\hline
\end{tabular}




\begin{tabular}{|l|c|c|c|}
\hline \multicolumn{1}{|c|}{ Atribut Layanan } & $\begin{array}{c}\text { Jawaban } \\
\text { Tertinggi }\end{array}$ & $\begin{array}{c}\text { Jawaban } \\
\text { Kedua } \\
\text { Tertinggi }\end{array}$ & $\begin{array}{c}\text { Jawaban } \\
\text { Ketiga } \\
\text { Tertinggi }\end{array}$ \\
\hline 14. Memberikan pelayanan yang akurat & $\mathrm{O}$ & $\mathrm{M}$ & $\mathrm{A}$ \\
\hline 15. Sikap ramah dan sopan membantu & $\mathrm{M}$ & $\mathrm{O}$ & $\mathrm{A}$ \\
\hline $\begin{array}{l}\text { 16. Inisiatip petugas dalam } \\
\text { pasien }\end{array}$ & $\mathrm{M}$ & $\mathrm{O}$ & - \\
\hline 17. Komunikasi yang baik & $\mathrm{M}$ & $\mathrm{O}$ & $\mathrm{I}$ \\
\hline $\begin{array}{l}\text { 18.Perhatian pada pasien tanpa memandang } \\
\text { status sosial }\end{array}$ & $\mathrm{M}$ & $\mathrm{I}$ & $\mathrm{O}$ \\
\hline 19. Rasa simpantik petugas kepada pasien & $\mathrm{O}$ & $\mathrm{M}$ & $\mathrm{I}$ \\
\hline 20. Perhatian petugas kepada pasien & & & \\
\hline
\end{tabular}

Sumber: Penelitian, 2016

Frekuensi tingkat kepuasan tertinggi

Tabel 5. Frekuensi Tingkat Kepuasan Tertinggi

\begin{tabular}{|c|c|c|}
\hline Atribut Layanan & Jawaban Tertinggi & Jumlah \\
\hline 9 & $\mathrm{O}$ & 53 \\
\hline 4 & $\mathrm{O}$ & 50 \\
\hline 18 & $\mathrm{M}$ & 50 \\
\hline 1 & $\mathrm{O}$ & 49 \\
\hline 2 & $\mathrm{O}$ & 46 \\
\hline 20 & $\mathrm{O}$ & 46 \\
\hline 3 & $\mathrm{O}$ & 45 \\
\hline 6 & $\mathrm{M}$ & 45 \\
\hline 19 & $\mathrm{M}$ & 45 \\
\hline 11 & $\mathrm{M}$ & 44 \\
\hline 12 & $\mathrm{M}$ & 63 \\
\hline 16 & $\mathrm{M}$ & 44 \\
\hline 5 & $\mathrm{M}$ & 43 \\
\hline 17 & $\mathrm{M}$ & 43 \\
\hline 10 & $\mathrm{M}$ & 43 \\
\hline 15 & $\mathrm{O}$ & 42 \\
\hline 8 & $\mathrm{O}$ & 41 \\
\hline
\end{tabular}

Sumber: Penelitian, 2016

Berdasarkan rekapitulasi jawaban responden tingkat kepuasan tertinggi yang ditunjukkan pada Tabel 2 diatas dapat diketahui variabel - variabel pelayanan apa yang saja yang sangat berpengaruh terhadap tingkat kepuasan pasien Puskesmas Medang Kampai serta variabel-variabel apa saja yang tidak diharapkan keberadaanya oleh pasien puskesmas medang kampai. 


\section{Penilaian Better dan Worse tingkat kepuasan}

Dengan menggunakan rumus 1.dan rumus 2 dapat diketahui seberapa besar nilai better dan nilai worse. Better mengindikasikan seberapa banyak kenaikan kepuasan pelangan jika kita menyediakan fitur nya (A \& O ). Worse mengindikasikan seberapa banyak penurunan kepuasan pelangan jika kita tidak menyediakan fiturnya ( $\mathrm{O} \& \mathrm{M})$.

Tabel 6. Rekapitulasi nilai Better dan Worse

\begin{tabular}{|c|c|c|c|c|c|c|}
\hline No & $\mathrm{A}$ & $\mathrm{I}$ & $\mathrm{O}$ & $\mathrm{M}$ & Better & Worse \\
\hline 1 & 2 & 3 & 49 & 38 & 0,55 & 0,94 \\
\hline 2 & 5 & 5 & 46 & 36 & 0,55 & 0,89 \\
\hline 3 & 9 & 1 & 45 & 37 & 0,58 & 0,89 \\
\hline 4 & 2 & 6 & 50 & 34 & 0,56 & 0,91 \\
\hline 5 & 5 & 10 & 34 & 43 & 0,42 & 0,83 \\
\hline 6 & 4 & 10 & 33 & 45 & 0,40 & 0,84 \\
\hline 7 & 7 & 4 & 43 & 38 & 0,54 & 0,98 \\
\hline 8 & 8 & 6 & 41 & 37 & 0,53 & 0,84 \\
\hline 9 & 8 & 4 & 53 & 27 & 0,66 & 0,86 \\
\hline 10 & 10 & 7 & 32 & 43 & 0,45 & 0,81 \\
\hline 11 & 5 & 9 & 34 & 44 & 0,42 & 0,84 \\
\hline 12 & 3 & 5 & 21 & 44 & 0,26 & 0,91 \\
\hline 13 & 6 & 9 & 39 & 38 & 0,46 & 0,83 \\
\hline 14 & 12 & 4 & 41 & 35 & 0,57 & 0,82 \\
\hline 15 & 5 & 10 & 42 & 35 & 0,51 & 0,83 \\
\hline 16 & 6 & 5 & 37 & 44 & 0,46 & 0,88 \\
\hline 17 & 10 & 10 & 29 & 43 & 0,42 & 0,78 \\
\hline 18 & 3 & 7 & 32 & 50 & 0,38 & 0,89 \\
\hline 19 & 4 & 31 & 14 & 45 & 0,42 & 0,86 \\
\hline 20 & 3 & 6 & 46 & 37 & 0,53 & 0,90 \\
\hline
\end{tabular}

Sumber: Penelitian, 2016

Berdasarkan rekapitulasi nilai better dan worse yang ditunjukkan pada Tabel dapat diketahui seberapa besar kenaikan dan penurunan tingkat kepuasan pasien jika fitur dari pelayanan pasien disediakan atau tidak. Hasil pengukuran ini memungkinkan pihak puskesmas medang kampai untuk dapat menitik beratkan usaha-usaha perbaikan terhadap hal-hal atau atribut-atribut yang sangat berpengaruh terhadap kepuasan pasien puskesmas medang kampai.

\section{Analisis Kategori Kano}

Hasil pengukuran dengan menggunakan metode kano memungkinkan bagi pihak Puskesmas Medang Kampai untuk menitik beratkan usaha-usaha perbaikan kualitas untuk hal-hal yang benar-benar dianggap perlu oleh pasien puskesmas medang kampai.

Berikut ini adalah faktor-faktor atau indikatori yang mempengaruhi kepuasan pasien puskesmas medang kampai yang terbagi menjadi 4 kategori.

1. One dimensional

Adalah faktor yang dinilai sangat penting untuk diprioritaskan oleh pihak Puskesmas Medang Kampai karena tingkat kepuasannya berhubungan linear dengan kinerja atribut, sehingga sangat berpengaruh terhadap kenaikan dan penurunan tingkat kepuasan pasien.

Berdasarkan kategori One dimensional dari seluruh item pertanyaan yang diberikan kepada 92 responden diketahui persentase jawaban yang diberikan oleh responden untuk kategori tersebut adalah sebanyak $42,5 \%$. 


\section{Must be}

Adalah faktor-faktor yang masih dianggap perlu oleh pasien menjadi tidak puas apabila kinerja dari atribut yang bersangkutan rendah. Tetapi kepuasan pasien tidak akan meningkat jauh diatas netral meskipun kinerja dari atribut tersebut tinggi.Must be merupankan pernyataaan lemah dari kepuasan tetapi lebih positif dari netral. Berdasarkan kategori must ber dari seluruh item pertanyaaan pertanyaan yang diberikan kepada 92 responden diketahui persentase jawaban yang diberikan oleh responden untuk kategori tersebut adalah sebanyak $44,1 \%$.

\section{Simpulan}

Berdasarkan hasil pengolahan data dan analisis yang telah dilakukan maka dapat disimpulkan bahwa Tingkat yang mempengaruhi kepuasaan pelayanan pasien Puskesmas Medang Kampai adalah Kecepatan merespon keluhan pasien, keteraturan lapangan parkir, kebersihan lingkungan Puskesmas, kerapian penampilan petugas, keperhatian petugas terhadap pasien, kebaikan fasilitas Puskesmas, keramahan dan kesopanan petugas.

Adapun atribut yang sangat berpengaruh terhadap tingkat kenaikan kepuasaan Pasien Puskesmas Medang Kampai adalah (a). Cepat merespon keluhan pasienp pada atribut ini kenaikan kepuasan Pasien mencapai 66 \% jika pihak Puskesmas dapat memenuhinya (b). Kondisi fisik fasilitas Puskesmas. Pada atribut ini kenaikan kepuasan pasien mencapai $58 \%$ jika pihak Puskesmas dapat memenuhinya (c). Keakuratan dalam pelayanan.Pada atribut ini kenaikan kepuasan pasien mencapai 57 \% jika pihak puskesmas dapat memenuhinya.

Sedang atribut yang sangat berpengaruh terhadap penurunan kepuasan pasien Puskesmas Medang Kampai adalah sebagai berikut:

(a).Prosedur pelayanan. Pada atribut ini penurunan kepuasan pasien mencapai $98 \%$ jika pihak Puskesmas tidak dapat memenuhinya (b).Lingkungan puskesmas. Pada atribut ini penurunan kepuasan pasien mencapai $94 \%$ jika pihak Puskesmas tidak dapat memenuhinya (c). Kondisi lapangan parkir. Pada atribut ini penurunan kepuasan Pasien mencapai $91 \%$ jika pihak Puskesmas tidak dapat memenuhinya (d). Perhatian petugas kepada Pasien. Pada atribut ini penurunan kepuasan pasien mencapai $90 \%$ jika pihak puskesmas tidak dapat memenuhinya.

\section{Daftar Pustaka}

Aprilina, 2012.,Analisis atribut produk yang mempengaruhi kategori kepuasan konsumen dengan metode kano, Univ Brawijaya, Malang

Marpaung, R., 2011, Faktor Kepuasan Pasien Rawat Inap A Terhadap Kualitas Pelayanan Rumah Sakit Umum Daerah Kota Dumai Dengan Metode

Kano, Sekolah Tinggi Teknologi Dumai

Pratisto, Masalah Statistik dan Rancangan Percobaan dengan SPSS 12,Elek Media Komputindo Gramedia, Jakarta, 2005

Surya, S, Metode Penelitian.PT Raja Grafindo Persada, Jakarta, 2005

Tjiptono, F, Anastasia D, Total Quality Management, Yogyakarta, 2003

Tjiptono, F, 2005, Service Quality Service, edisi: 3 Yogyakarta

Sekolah Tinggi Teknologi Dumai, 2015, Panduan Penyusunan Penulisan Laporan Kerja Praktek dan Tugas Akhir, edisi ke V Dumai

Wijaya, Manajemen Kualitas Jasa,PT Indeks, Jakarta, 2011

Market shareSmarthphone online www.gogle.com diakes pada tanggal

3 Nopember 2015 